\title{
EU LHE ALEMBRO A VOCÊ: SOBRE O LUGAR DE VOSSA MERCÊ E VOCÊ NA HISTÓRIA DO PORTUGUÊS
}

\author{
EU LHE ALEMBRO A VOCÊ: ABOUT THE SPACE \\ OF VOSSA MERCE AND VOCÊ IN THE HISTORY OF PORTUGUESE
}

\author{
Vanessa Martins do Monte | Lattes |vmmonte@usp.br \\ Universidade de São Paulo
}

Resumo: A mudança nas normas de polidez afeta e reconfigura o sistema de tratamentos de uma dada língua. Localizar fontes primárias escassas, como os manuscritos quinhentistas e seiscentistas, permite que se estude, para além das formas de tratamento, a formação de um novo acordo de polidez, assentado em uma nova sociedade que começa a se formar em meados do século XVI na América Portuguesa. São índices desse novo sistema as formas vossa mercê e você. Os arranjos feitos no início do processo de colonização afetaram as formas e funções de cortesia do que viria a se tornar o português brasileiro (PB), daí a ênfase que damos aos séculos XVI e XVII. Investigamos neste texto (a) fontes documentais manuscritas quinhentistas e seiscentistas que trazem ocorrências abundantes de vossa mercê e que nunca foram analisadas em pesquisas sobre formas de tratamento; (b) o uso das formas vossa mercê e você a partir de uma obra literária e de fontes metalinguísticas; e tecemos observações à luz da investigação proposta. Uma das contribuições deste artigo é a atestação do terminus a quo da palavra você, que data de 1638 . Outras decorrências da análise levada a cabo são a defesa de uma necessária interdisciplinaridade dos estudos de Filologia, Paleografia e Linguística Histórica, além da constituição de um diálogo efetivo entre os projetos coletivos estaduais que pesquisam a história do $\mathrm{PB}$, considerando-se sua sócio-história comum.

Palavras-chave: Filologia; Etimologia; Formas de tratamento; Vossa mercê; Você.

\begin{abstract}
The change in politeness rules affects and reconfigures the treatment system of a given language. Finding scarce primary sources, such as the $16^{\text {th }}$ and $17^{\text {th }}$ century manuscripts, allows us to study, in addition to the forms of treatment, the formation of a new politeness agreement. This new agreement is based on a new society that began to be formed in American Portuguese.in the middle of the $16^{\text {th }}$ century The indices of this new system are the forms vossa mercê and você. The arrangements made at the beginning
\end{abstract}


of the colonization process affected the courtesy forms and functions of what would become the Brazilian Portuguese (BP), which are the reasons why this paper emphasizes the $16^{\text {th }}$ and $17^{\text {th }}$ centuries. We investigate in this article (a) manuscripts produced between 16th and $17^{\text {th }}$ centuries that have never been analysed by the perspective of the Portuguese's address system and (b) the use of vossa mercê and você in literary texts and in metalinguistic sources. In the end of the paper, final observations are made in the light of the proposed research. One of the contributions made by this study is the register of the terminus a quo of the word você, which dates from the year 1638 . We argue for the interdisciplinarity of Philology, Paleography and Historical Linguistics studies and for the constitution of an effective dialogue between the state collective projects that investigate the BP history, considering its common socio-history.

Keywords: Philology; Politeness; Forms of address; Etymology; Vossa mercê; Você.

\section{Introdução}

O estudo das formas de tratamento em português tem se concentrado no período do século XVIII em diante. Não se pode deixar de lado, no entanto, os séculos iniciais de formação de uma nova sociedade na América Portuguesa. As relações que vão se forjando nesse contexto interessam imensamente a esse estudo, uma vez que a criação de novos acordos de polidez provoca alterações no sistema de tratamentos, reconfigurando-o. São índices dessa reconfiguração as formas vossa mercê e você. O estudo desse fenômeno linguístico em tal período impõe dificuldades consideráveis, uma vez que são raros os manuscritos quinhentistas e seiscentistas lavrados na América que nos restaram e ainda mais escassos aqueles que nos fornecem pistas histórico-linguísticas confiáveis para o estudo. Com base em uma perspectiva filológica, defende-se que os arranjos feitos no início do processo de colonização afetaram as formas e funções de cortesia, criando, desde muito cedo, o quadro de tratamentos que caracterizará o português brasileiro (PB).

A quantidade de pesquisas sobre as formas de tratamento em língua portuguesa é digna de destaque. $\mathrm{O}$ fato de haver um conjunto comparativamente amplo de formas distintas para se referir ao interlocutor é uma das explicações para o volume de investigações. Comparando-se ao francês, que possui o formal vous em contraste ao informal $t u$, a língua portuguesa apresenta $t u$, você e variantes no tratamento informal, e o/a senhor/a no formal, dentre outras expressões. Tanto no português europeu contemporâneo quanto no português brasileiro verifica-se variedade de formas nas dimensões formal, informal 
e neutra (COOK, 1997, 2013). Tais formas não são, em sua maioria, pragmaticamente coincidentes nos sistemas de polidez português e brasileiro (LOPES et al., 2018).

A investigação mais recente sobre a formação de sistemas pronominais distintos no português brasileiro e no português europeu contemporâneo se deve mormente aos amplos e profícuos projetos de investigação sobre a história da língua portuguesa no Brasil. Iniciativas como o PHPB - Projeto para a História do Português Brasileiro - e suas ramificações regionais lançaram luz ${ }^{1}$ sobre esse aspecto que já era fruto de reflexões importantes (CINTRA, 1972; LUZ, 1958).

Os estudos que se produziram tendo como foco a representação pronominal de segunda pessoa do singular frequentemente centram-se na observação dos pronomes em si e dos seus paradigmas. Para estudos de natureza diacrônica, no entanto, propõe-se aqui a volta do olhar para o sistema de polidez, do qual são índices as formas nominais e pronominais de tratamento. Advoga-se a favor da observação do fenômeno dos tratamentos a partir da conformação de um novo sistema de cortesia, o que traz reflexões importantes sobre a formação do sistema pronominal do PB. São índices desse novo sistema as formas vossa mercê e você, daí a ênfase dada a essas expressões neste artigo.

Adota-se como pressupostos teóricos para a abordagem proposta aqueles trazidos pela Filologia, aqui entendida como uma perspectiva de estudo do texto escrito e de valor histórico. Como se trata de pesquisa com viés diacrônico que remonta ao início da formação do Brasil, é necessário que se lidem com textos escritos, manuscritos ou impressos. $\mathrm{O}$ exame de tais textos prima pela análise de sua materialidade (TOLEDO NETO, 2018). Em estudos linguísticos, sobretudo aqueles que têm como centro as formas de tratamento, é indispensável que se levem em conta aspectos codicológicos e paleográficos, tendo em vista que as abreviaturas são a forma convencional de registrarem-se a forma você, geralmente abreviada $v$, e as demais fórmulas corteses de tratamento.

Este artigo se divide em três partes. Na primeira, apresenta-se uma análise a partir de documentos manuscritos, que se revelam fontes importantes para a investigação das formas você e vossa mercê. O corpus de documentos manuscritos foi construído a partir de cartas privadas publicadas pelo Projeto P.S. Post Scriptum (CLUL, 2014), seguindo rigorosos pressupostos filológicos e eletronicamente processadas.

Na segunda parte, trazemos alguns comentários sobre as mesmas formas a partir de fontes metalinguísticas e de uma das raras obras literárias em que se atesta o uso de vossa mercê. As fontes metalinguísticas utilizadas foram dois dicionários de Raphael Bluteau

\footnotetext{
${ }^{1}$ O PHPB é um projeto idealizado pelo Professor Emérito Ataliba de Castilho, da Universidade de São
} Paulo. Destaca-se, na área dos tratamentos, a publicação de autoria de Lopes et. al., publicada em 2018. 
$(1712-1728,1721)$ e a Ortographia, ou arte de escrever, e pronunciar com acerto a lingua portugueza para uso do excellentissimo Duque de Lafoens [...] de Madureira Feijó (1734). À exceção das obras de Gil Vicente, de onde são frequentemente extraídos os exemplos de usos das formas de tratamento (cf. CINTRA, 1972), são escassos e praticamente desconhecidos os textos literários quinhentistas e seiscentistas que atestam as formas analisadas. Por isso, decidimos nos valer da edição crítica da obra de Jorge Ferreira de Vasconcelos, a Comédia Ulissipo, provavelmente publicada em 1561 (SANTOS, 2006). Por conta da raridade das fontes, ressalvamos que a segunda parte do artigo é comparativamente mais exígua do que a primeira.

Na terceira e última parte, tecem-se observações finais à luz da investigação proposta.

\section{$2(\mathrm{Re})$ contando a história de vossa mercê e você por meio de documentos}

O pioneirismo do estudo sobre as formas de tratamento em português costuma ser atribuído à Marilina dos Santos Luz (1958). Uma das frases célebres da autora e que ainda motiva muitas das pesquisas recentes sobre nosso complexo sistema de tratamentos é a seguinte: "A maior revolução no sistema de tratamento português foi provocada pelo aparecimento da terceira pessoa do singular, aplicada à segunda pessoa do discurso.” (LUZ, 1958, p. 49).

Sobre as formas que nos interessam mais de perto neste artigo, Luz (1958) situa o uso da expressão "pedir por mercê” nas Cantigas de Santa Maria, de Afonso X, datadas do séc. XIII. Os primeiros registros escritos de vossa mercê são atestados nas atas das cortes de 1331. Durante todo o século XIV, o uso da forma ainda é tímido e não concorre com outras formas para se dirigir ao rei, o que passa a acontecer apenas no segundo quartel do século XV. Luz (1958) afirma ainda que as crônicas quatrocentistas de Fernão Lopes atestam mais frequentemente o uso de vós e de senhor para se dirigir ao rei, apesar de registrarem também o tratamento vossa mercê tanto para o rei quanto para a rainha. Segundo Cintra (1972), as formas vossa mercê, vossa alteza e vossa senhoria são sempre proferidas por estrangeiros, castelhanos ou italianos, nas crônicas de Lopes. Nas cortes de 1490, no entanto, Luz (1958) não encontra ocorrências de vossa mercê.

O século XV, segundo o levantamento feito por Luz (1958), assiste à proliferação de formas de tratamento honoríficas, usadas para se dirigir ao rei, mas também aos nobres da corte. Data desse século também a criação das dignidades de duque, marquês, barão e visconde (LUZ, 1958, p. 135). A forma vossa senhoria é atestada pela primeira vez em 1442 , como tratamento real, passando a concorrer com vossa mercê. A forma vossa alteza 
também começa a ser usada para o tratamento régio. A forma mais frequente durante $o$ quatrocentos, no entanto, ainda é vossa mercê, segundo atestam os documentos estudados por Luz (1958). Do século XV em diante, entretanto, a forma vossa senhoria "fixa-se num nível nitidamente superior ao de Vossa Mercê. Por isso, durante séculos, vai tornar-se numa aspiração de todo aquele que quer subir na escala social o ser tratado por Vossa Senhoria." (CINTRA, 1972, p. 22).

Cintra (1972), outro nome de referência na área de estudos concernentes ao tratamento, analisa detidamente a obra de Gil Vicente, indicando ser a adequação do tratamento uma preocupação generalizada daqueles que viviam nas cidades durante os quinhentos. Segundo Cintra (1972, p. 56), nas farsas e comédias vicentinas, a forma vossa mercê se alternava com vós, sendo usada "com certa parcimónia, sempre que um personagem deseja mostrar-se particularmente cortês para com outro pertencente àquilo que poderemos considerar a pequena burguesia das grandes cidades”.

Ao final do séc. XVI, atesta-se uma expansão do tratamento vossa mercê, fato que teria pressionado a corte a publicar as chamadas Leis de Cortesia ou Leis dos Tratamentos. A primeira delas foi publicada em 1597, e vossa mercê consta apenas do interior da fórmula epistolar de encerramento "Deus guarde a vossa mercê". É importante notar, portanto, que o tratamento vossa mercê não servia mais nem para tratar a pequena burguesia urbana, muito menos os nobres. Segundo Durães (2017, p. 87):

A codificação dos graus de honra era uma prerrogativa real e este foi um dos aspetos no qual o rei não se coibiu de exercer o seu poder normalizador. As sucessivas Leis dos Tratamentos, publicadas em 1597, 1611 e 1739, ampliada em 1759, ao definirem uma elite restrita merecedora dos distintivos epítetos de Excelência, Senhoria e Dom, acabaram por contribuir para a delimitação formal e objetiva da camada superior da sociedade.

Sobre a lei de 1739, Monte (2015, p. 419-420) afirma que

D. João $\mathrm{V}$, devido à confusão que se sucedia nos tratamentos e à extensão no uso de vossa senhoria, é obrigado a promulgar uma nova lei. O monarca revoga o conteúdo da lei de 1597, à exceção da parte em que se dispõem os tratamentos devidos ao rei, às rainhas, aos príncipes herdeiros, princesas, infantes e infantas. Nota-se, assim, que as formas mais especializadas, dirigidas aos representantes máximos do poder monárquico, a saber majestade e alteza, não sofreram muitas transformações, nem parecem ter sido utilizadas indevidamente.

A Figura 1, a seguir, apresenta um esquema representativo das informações centrais sobre as formas de tratamento trazidas por Luz (1958) e Cintra (1972): 
Figura 1 - Esquema da evolução das formas de tratamento em português, de acordo com Luz (1958) e Cintra (1972)

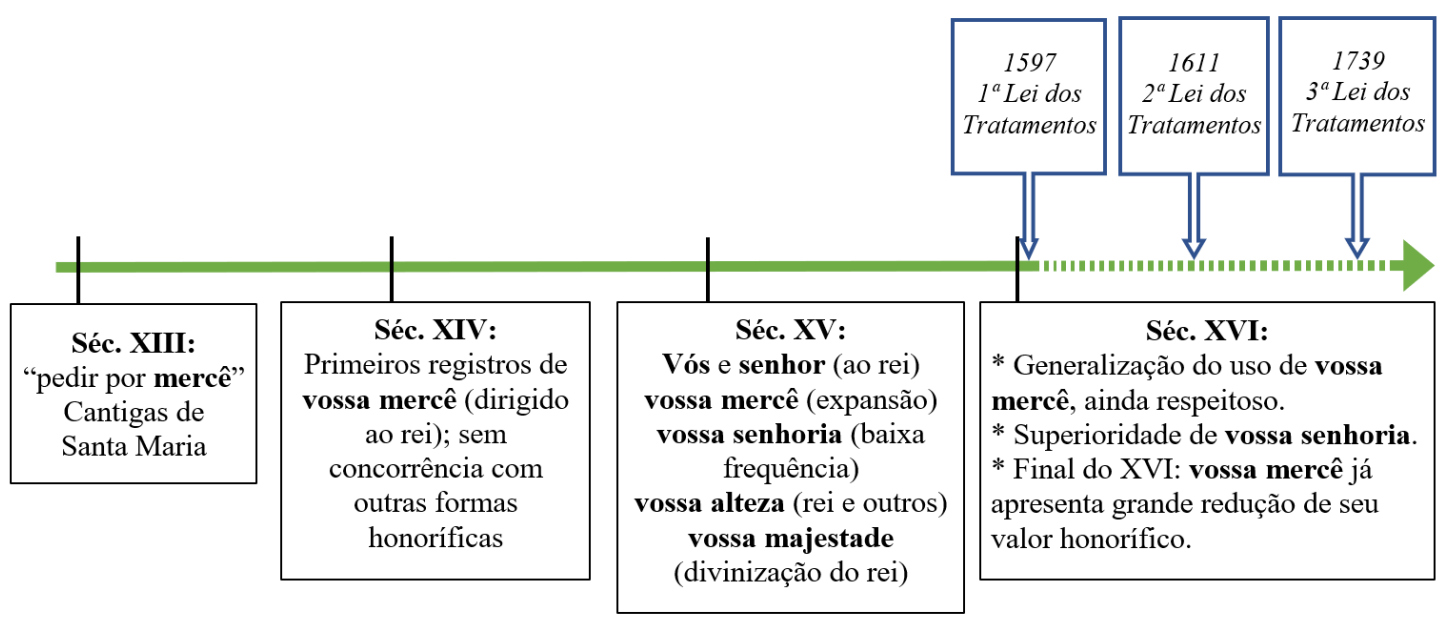

Fonte: Da autora.

A tentativa de atestar a primeira ocorrência da forma você na língua portuguesa costuma atribuí-la ao texto Feira de Anexins, de D. Francisco Manuel de Melo, datando-a de 1665 ou 1666. O ano de 1665 é a data que consta, por exemplo, do Dicionário Houaiss (HOUAISS, VILLAR, 2012). A informação do ano de 1666 como a primeira ocorrência de você ficou cristalizada e é amplamente disseminada na literatura linguística, como mostra detalhadamente Franco (2017). Menon $(2006,2009)$ também discute a datação a partir das obras de Francisco Manuel de Melo, levantando a hipótese de a forma não ser corrente à época e ter sido fruto de uma alteração editorial, de um suposto vossa mercê ao reduzido você, promovida quando de sua primeira publicação, quase dois séculos depois, em 1875.

Fato é que, tanto do ponto de vista filológico quanto etimológico ${ }^{2}$, a data a ser considerada para a ocorrência seria o ano de 1875, que é a data efetiva da publicação da obra. Até que se encontre a primeira versão manuscrita seiscentista ou mesmo alguma edição impressa da obra anterior a 1875, da qual não se tem notícia, a data fidedigna da primeira ocorrência de você, ou terminus a quo, tem de ser a data efetiva de quando a obra Feira de Anexins veio a lume:

\footnotetext{
2 Sobre a questão do estabelecimento do terminus a quo nas pesquisas etimológicas, ver Viaro \& Bizzocchi, 2016. Nos trabalhos envolvendo a construção do DELPo - Dicionário Etimológico da Língua Portuguesa (https://delpo.prp.usp.br/) -, nos deparamos com a necessidade de atestar rigorosamente a data de publicação da obra sob o risco de atestar uma falsa ou discutível retrodatação.
} 


\begin{abstract}
É importante salientar que se trata de um texto editado após a morte do autor. A datação de 1666 acabou sendo atribuída por ser esse o ano de falecimento de D. Francisco Manuel de Melo. A obra foi publicada pela primeira vez em 1875, por Inocêncio Francisco da Silva, e sua segunda edição foi revisada em 1916. (FRANCO, 2017, p. 39)
\end{abstract}

A alusão à história da retrodatação da forma você indica um procedimento que foi bastante corrente nos estudos diacrônicos de forma geral, que é o de buscar atestações em documentos impressos. Atualmente, no entanto, com a ampla gama de edições de textos manuscritos preparadas com rigor filológico e com o avanço das pesquisas em Humanidades Digitais (PAIXÃO DE SOUSA, 2013), já é bastante possível a investigação em corpora eletrônicos abertos e online. Um deles é o Projeto P.S. Post Scriptum, coordenado por Rita Marquilhas (CLUL, 2014). Nele, encontram-se fac-símiles de cartas privadas escritas durante a Idade Moderna em Portugal e na Espanha, acompanhados de suas edições conservadora e modernizada.

A vantagem de corpora idealizados a partir das ferramentas das Humanidades Digitais é, por exemplo, as inúmeras possibilidades de busca nos textos editados. Por meio desta busca relativamente simples, realizada no site do Projeto P.S. Post Scriptum, já é possível retrodatar a forma você, grafada uose, para 1638, conforme Figura 2 a seguir:

Figura 2 - Ocorrência de uose em trecho de carta de João Bulhão, de 1638

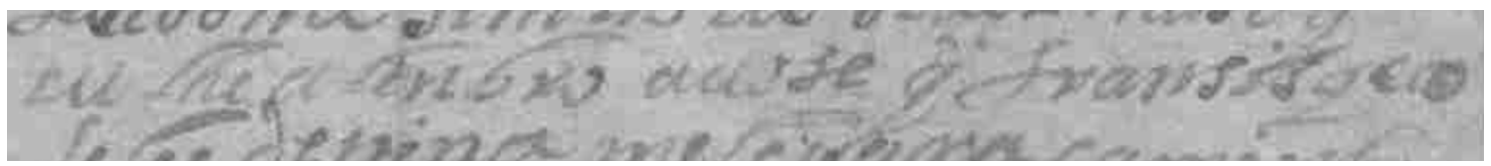

Transcrição: eu lhe alenbro a uose q fransisquo

Fonte: CLUL, 2014.

A carta em questão foi escrita pelo cardador João Mendes Bulhão, de 46 anos, que havia sido preso por judaísmo pelo Tribunal do Santo Ofício - Inquisição de Évora. Ele escreve a Jerónimo Gomes, fazendo-lhe ameaças veladas e pedindo-lhe ajuda por estar passando necessidades na prisão, conforme se lê na ficha catalográfica do documento (CARDS4008 - CLUL, 2014).

Continuando a pesquisa no mesmo corpus eletrônico, encontram-se duas missivas datadas de 1672 escritas por mulheres, Raquel da Silva e, sua filha, Sara da Silva, a Isaac del Sotto, respectivamente pai e avô das missivistas (PSCR1475 e PSCR1483 - CLUL, 2014). Tanto a filha quanto a neta o tratam por você, grafado voce. 
Figura 3 - Ocorrência de uoce em trecho inicial de carta de Raquel da Silva, de 1672

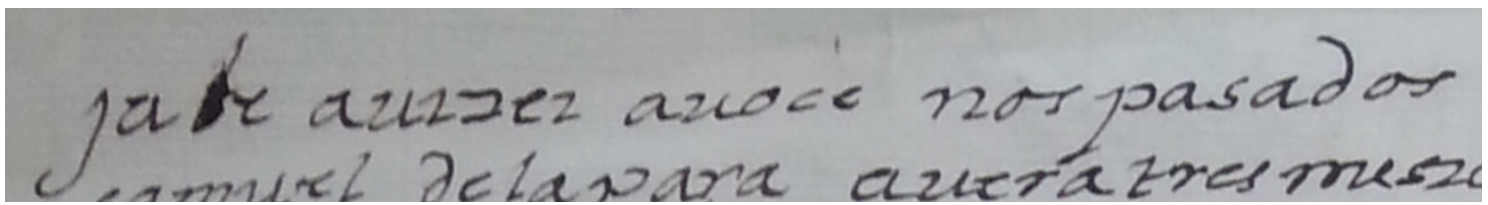

Transcrição: ja [1] e auizei a uoce nas passadas

Fonte: CLUL, 2014.

Figura 4 - Ocorrência de uoce em trecho medial de carta de Raquel da Silva, de 1672

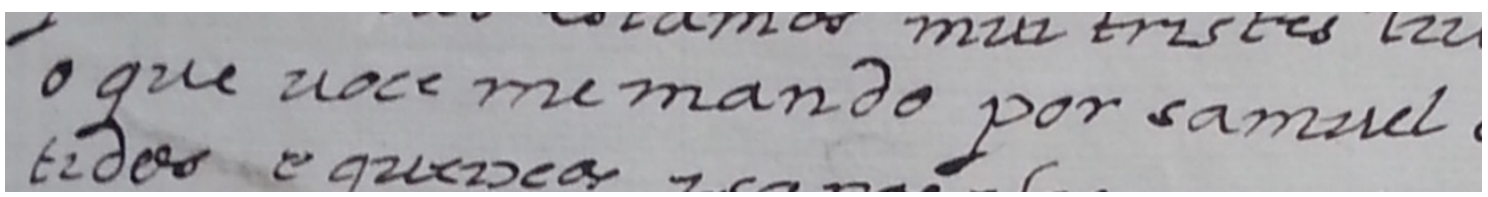

Transcrição: o que uoce me mando por samuel

Fonte: CLUL, 2014.

Figura 5 - Ocorrência de uoce em trecho de carta de Sara da Silva, de 1672

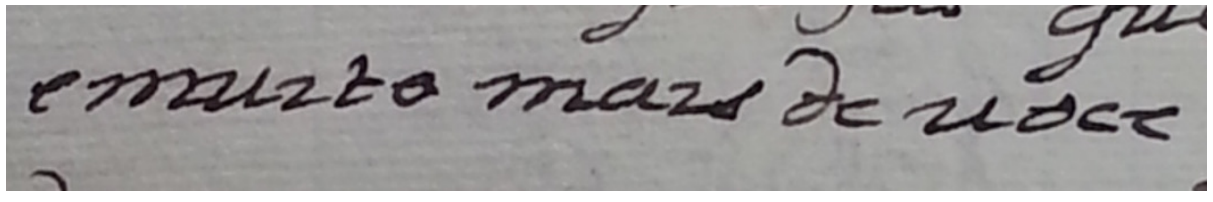

Transcrição: e muito mais de uoce

Fonte: CLUL, 2014.

As cartas foram escritas desde o Suriname a Amesterdão e têm como tema comum o receio da invasão por potências estrangeiras ${ }^{3}$. Nota-se que a grafia é idêntica nas três ocorrências, com o uso sistemático de $u$ por $v$, conforme é frequente em documentos do período. Assim como na missiva de 1638, não se nota aqui nenhum vestígio gráfico que pudesse indicar a tentativa de abreviar uma suposta forma de tratamento vossa mercê.

\footnotetext{
${ }^{3} \mathrm{O}$ contexto mais geral das cartas, segundo nos informa a ficha catalográfica dos documentos, é este: "Perante a suspeita de as comunidades sefarditas traficarem mercadorias e informações em prejuízo da Coroa inglesa, várias embarcações procedentes ou destinadas à Holanda por sua conta foram intercetadas. Efetivamente, as disposições constantes nos Atos de Navegação de Cromwell proibiam o trato comercial das colónias inglesas com a Holanda, a Espanha, a França e respetivas possessões ultramarinas. Os processos instaurados, à guarda no Supremo Tribunal do Almirantado, surgem no contexto de quatro momentos de grande crispação entre aquelas duas potências [...]. A documentação encontrada a bordo e preservada em arquivo - correspondência particular e registos de carga - constituiu testemunho documental da prática dos crimes de contrabando de mercadorias em alto mar. As cartas aqui descritas são ainda demonstrativas da qualidade das relações mantidas no seio de famílias sefarditas (judeus e conversos), com existência de redes estrategicamente distribuídas: de um lado, os colonos posicionados abaixo da linha do equador, mais precisamente numa área das Sete Províncias das Índias Ocidentais (o Caribe), no âmbito das possessões ultramarinas holandesas; do outro, familiares e parceiros de negócio, situados nos principais portos no Atlântico Norte, importantes centros de atividade financeira e mercantil.”. (CLUL, 2014)
} 
É bastante provável, portanto, que na língua falada, menos conservadora do que a escrita, a forma você já circulasse amplamente entre o final do século XVI e o início do século XVII. A investigação continuada em arquivos que contenham manuscritos desse período provavelmente revelará mais ocorrências da forma você e correlatas. Assim, é previsível que se recue ainda mais a sua primeira ocorrência.

Cabe comentar um raro exemplo encontrado no mesmo Projeto Post Scriptum. Trata-se de carta escrita por Estêvão de Torres à sua mulher Anna, originalmente em francês e cuja tradução foi ditada

pelo próprio por ordem dos inquisidores e registadas nas atas das sessões de interrogatório. Estêvão de Torres, residente havia dez anos em Portugal, foi preso pela Inquisição a 19 de setembro de 1549, acusado de comer carne durante a Quaresma e outros dias defesos e de crer e proferir afirmações consideradas heréticas. (CLUL, 2014)

O interessante desta carta é que a tradução do francês ao português conserva o pronome vous como vós, à exceção do trecho em que ele aparece numa fórmula epistolar e é traduzido por vossa merce: "encõmendome em vossa merce" (PSCR1149 - CLUL, 2014). Vejamos as Figuras 6 e 7 a seguir com as imagens dos manuscritos:

Figura 6 - Trecho de carta em francês de Estêvão de Torres, de $1549^{4}$

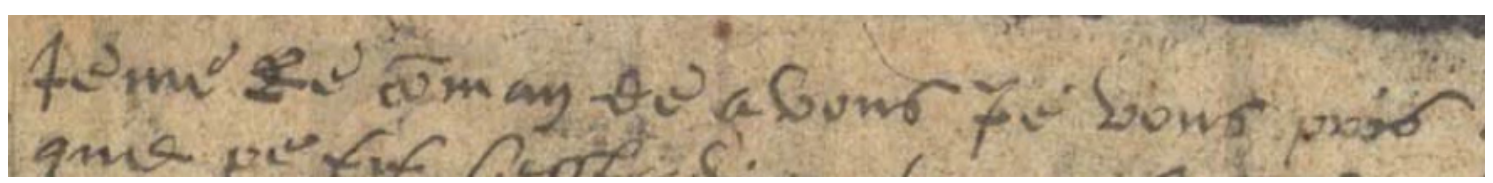

Transcrição: Je me recõmande a vous je vous pris

Fonte: Arquivo Nacional da Torre Tombo, PT/TT/TSO-IL/028/00350.

Figura 7 - Trecho da tradução da carta de Estêvão de Torres, de 1549, constante do processo inquisitorial

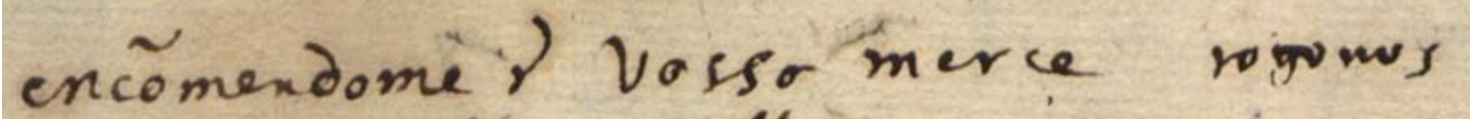

Transcrição: encõmendome ẽ vossa merce rogo uos

Fonte: Arquivo Nacional da Torre Tombo, PT/TT/TSO-IL/028/00350.

\footnotetext{
${ }^{4}$ A carta em questão faz parte do processo de Estêvão de Torres e foi localizada diretamente no acervo digitalizado do Tribunal do Santo Ofício no site do Arquivo Nacional da Torre do Tombo (doravante ANTT) (http://digitarq.dgarq.gov.pt/).
} 
O exemplo da Figura 7 atesta o uso da forma vossa merce por extenso, sem sinais gráficos que indiquem tentativa de abreviação. Além disso, mostra que a forma é inserida numa estrutura altamente formulaica, presente em ambas as línguas românicas. Luz (1958) indica que a fórmula "me recomendo em vossa mercê" era bastante utilizada em epístolas, citando uma missiva do cronista Zurara ao rei de Portugal em que a referida fórmula aparece.

Com o objetivo de verificar se haveria outros exemplos da forma vossa merce escrita por extenso, efetuou-se uma busca exaustiva no corpus do Projeto Post Scriptum. Foram encontradas muitas ocorrências da forma escrita sem abreviaturas, como se observa na Quadro 1.

Quadro 1 - Exemplos da ocorrência de vossa merce por extenso

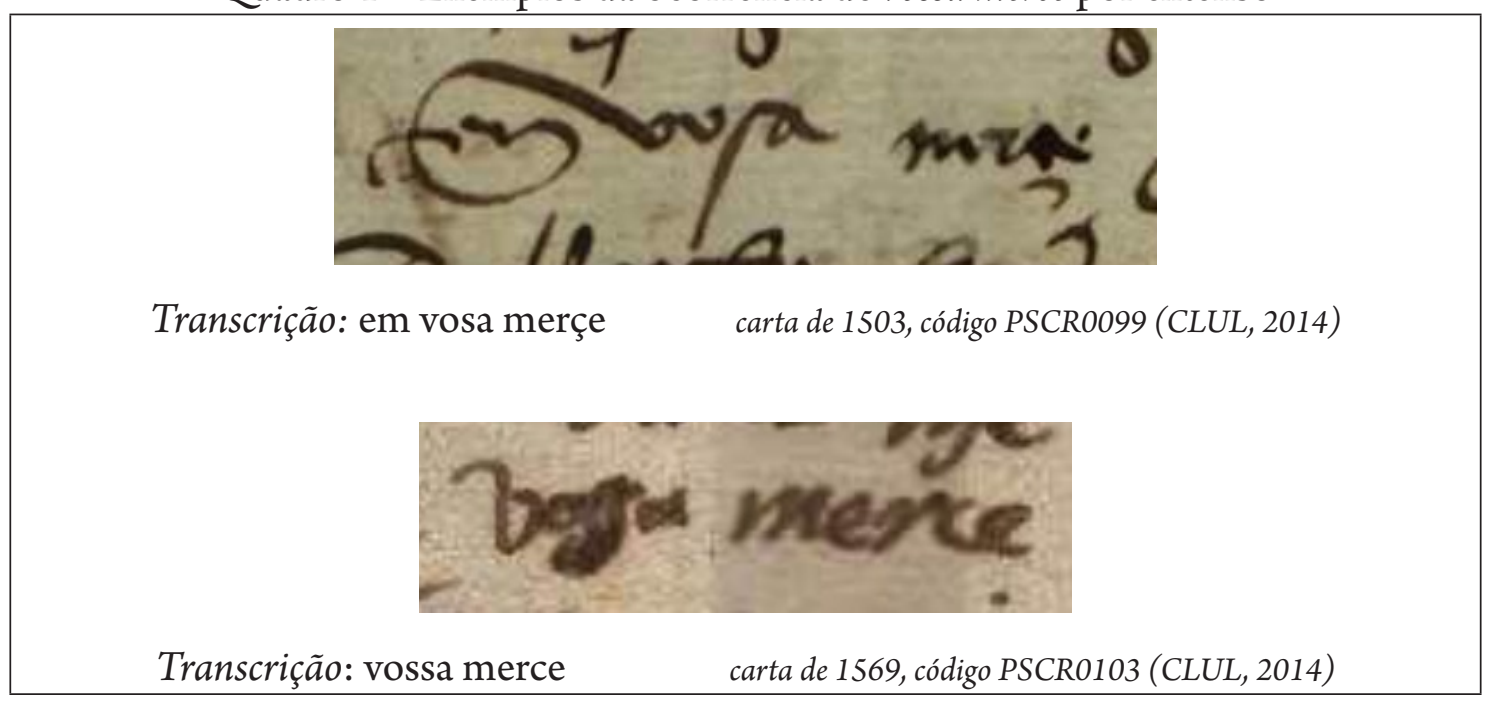

Fonte: CLUL, 2014.

No Quadro 2 a seguir trazem-se os resultados dessa busca. Na primeira coluna, apresenta-se a numeração dos documentos em ordem crescente. Na segunda coluna, há o código do documento no corpus do Projeto Post Scriptum, com link clicável para facilitar o acesso. Na terceira, indica-se o ano em que a carta foi escrita ou, em alguns casos, um intervalo aproximado. Na quarta coluna, encontra-se a transcrição conservadora das formas e, por fim, a quinta coluna apresenta a imagem recortada da forma de tratamento. 
Quadro 2 - Relação de documentos com a forma vossa merce e variantes gráficas ${ }^{56}$

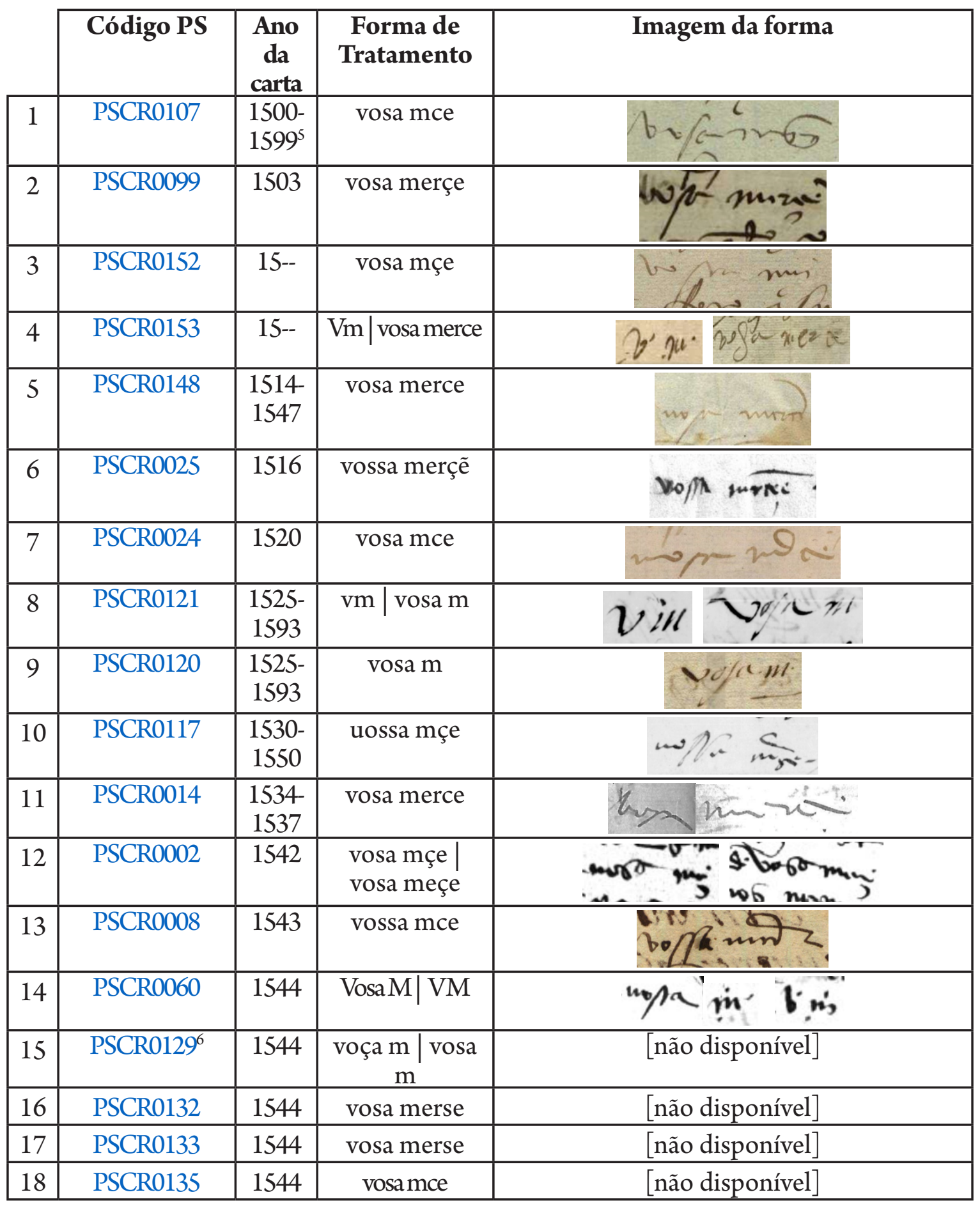

${ }^{5}$ Algumas cartas possuem datação aproximada.

${ }^{6}$ Esta carta bem como as duas seguintes pertencem "a um conjunto de dezoito cartas quinhentistas existentes no Arquivo Geral da Bélgica, em Bruxelas. Este conjunto de cartas foi escrito essencialmente entre os dias 20 e 25 de junho de 1544 e enviado de Lisboa a parentes e amigos residentes na Flandres. Segundo os dados apurados pelo arquivo onde estão alojadas, estas cartas foram enviadas por via marítima e terão sido apreendidas numa ação naval, nunca chegando à posse dos destinatários. Não se encontrou informação da data em que as cartas integraram as coleções do Arquivo Geral Belga.” (CLUL, 2014). É provável que, por não pertencerem ao Arquivo Nacional da Torre do Tombo (ANTT), as cartas não tenham sido digitalizadas ou mesmo não se tenha obtido autorização para a divulgação das imagens. 


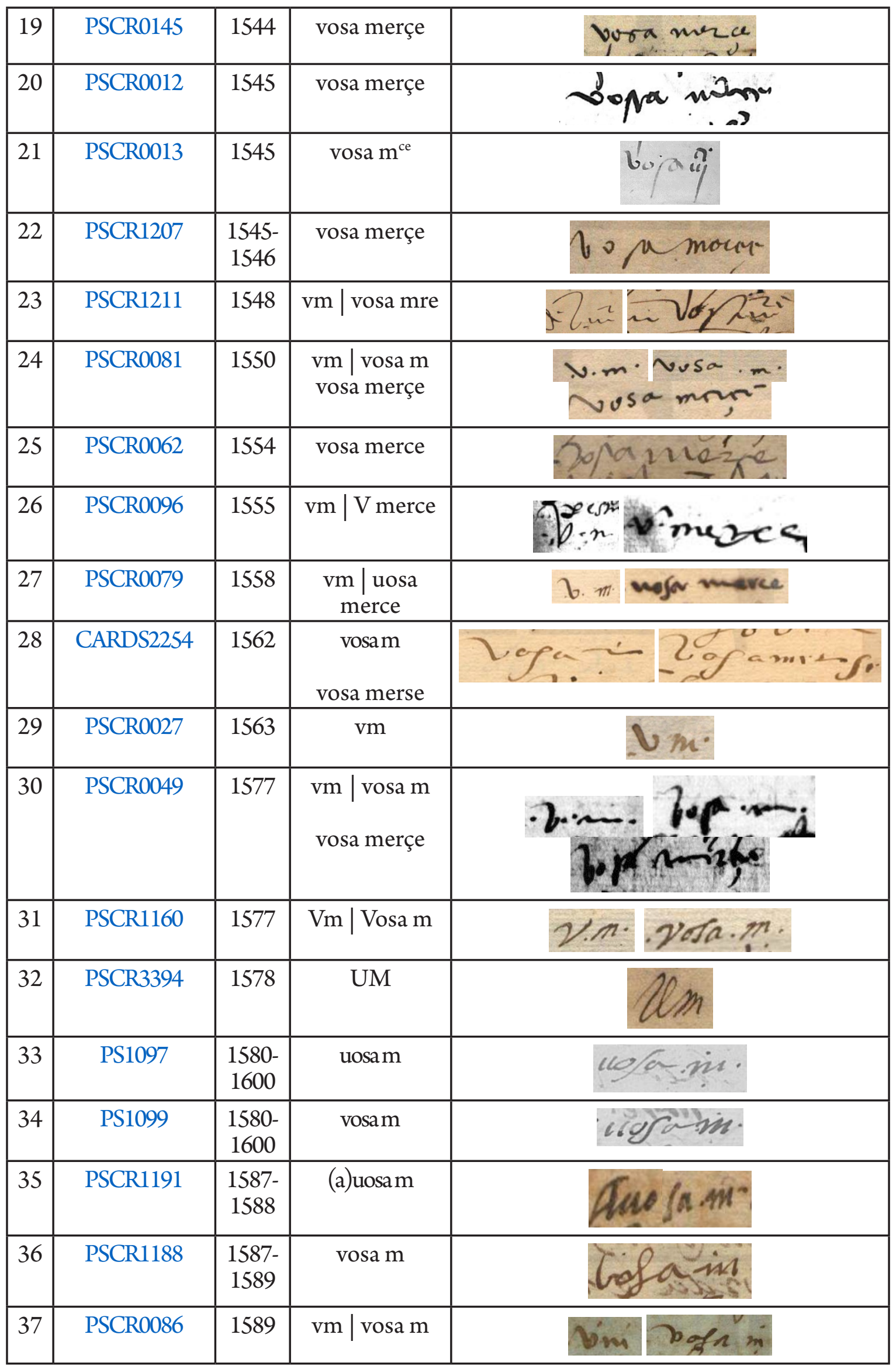




\begin{tabular}{|c|c|c|c|c|}
\hline 38 & PSCR0087 & 1589 & vm | vosa m & pha \\
\hline 39 & PS2517 & 1592 & $\operatorname{vos}(\mathrm{s})$ a merce & vofa merce. \\
\hline 40 & PSCR0045 & 1593 & $\begin{array}{l}\text { um | uosa } \\
\text { merce }\end{array}$ & nom uvfa ma \\
\hline 41 & PSCR1134 & 1597 & $\begin{array}{l}\text { vm | vosa } \\
\text { merce }\end{array}$ & $\hat{v} m$ \\
\hline 42 & PSCR1277 & 1600 & $\mathrm{Vm}$ & \\
\hline 43 & PSCR1391 & 1611 & VM & \\
\hline 44 & PSCR0380 & 1614 & \begin{tabular}{c|c}
$\mathrm{Vm}$ & vosa mer \\
& vosa $\mathrm{m}$
\end{tabular} & [não disponível] \\
\hline 45 & CARDS3040 & 1617 & vm | uossa m & fa: \\
\hline 46 & PSCR3397 & 1619 & (a)VM & \\
\hline 47 & PS1042 & $\begin{array}{l}1619- \\
1621\end{array}$ & $\begin{array}{c}\text { um } \mid \text { uosa } \\
\text { merse }\end{array}$ & \\
\hline 48 & PSCR0443 & 1623 & $\begin{array}{l}\text { vm | uosa } \\
\text { merce }\end{array}$ & $\omega \dot{m}^{\circ}$ \\
\hline 49 & PSCR0444 & 1623 & $\begin{array}{l}\text { vm } \mid \text { uosa } \\
\text { merce }\end{array}$ & ning \\
\hline 50 & PSCR1359 & 1623 & uosa $\mathrm{m}$ & $\dot{m}$. \\
\hline 51 & CARDS1040 & 1646 & $\mathrm{vm} \mid$ uosa $\mathrm{m}^{\mathrm{ce}}$ & \\
\hline 52 & CARDS1034 & 1663 & vosa mersse & 20 \\
\hline 53 & PSCR1399 & 1672 & $\mathrm{Vm}$ & \\
\hline 54 & PSCR1398 & 1672 & VM & \\
\hline 55 & CARDS1095 & 1708 & uosa merçe & orese \\
\hline 56 & PSCR0541 & 1715 & VM & \\
\hline 57 & PS1046 & 1734 & $\mathrm{Vm}$ & \\
\hline 58 & CARDS2166 & 1776 & $\mathrm{VM}^{\mathrm{ce}}$ & tee \\
\hline
\end{tabular}




\begin{tabular}{|c|c|c|c|c|}
\hline 59 & CARDS0037 & 1791 & $\mathrm{vm}^{\mathrm{ce}}$ & \\
\hline 60 & CARDS6264 & 1803 & $\mathrm{Vm} \mid \mathrm{Vm}^{\mathrm{ce}}$ & \\
\hline 61 & CARDS6269 & 1803 & $\mathrm{vm}^{\mathrm{e}}$ & \\
\hline 62 & CARDS7140 & 1819 & Vossa merçe & \\
\hline 63 & CARDS7149 & 1819 & Voça merçe & Poen \\
\hline
\end{tabular}

Fonte: Dados obtidos de CLUL, 2014.

A carta de no 1 (PSCR0107) mostra a importância de considerarmos a materialidade documental ao se investigar as formas de tratamento em uma pesquisa diacrônica. Fosse pela transcrição conservadora disponível no site do Projeto Post Scriptum, consideraríamos três variantes: vosa me, vosa merce e Vmce. A observação do original digitalizado, no entanto, permite que se veja claramente que se trata de apenas uma forma gráfica (conforme Figura 8 a seguir) que se repete ao longo da carta.

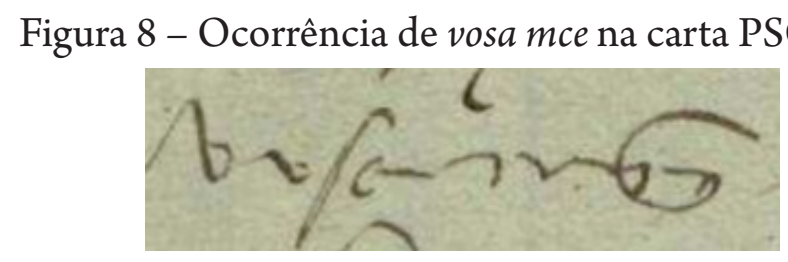

Fonte: CLUL, 2014.

O mesmo ocorre com a carta de no 9 (PSCR0120), cuja transcrição conservadora indica a forma vosa $m$, e com a missiva no 58 (CARDS2166), que apresenta a forma Vossa Mce na transcrição. Nenhuma das formas que traz o Vossa sistematicamente abreviado $V$ é observada no manuscrito. Assim, comprova-se a indispensabilidade do contato com a reprodução fac-similar do manuscrito, a fim de se realizar observação paleográfica acurada, bem como a ampla facilidade que as ferramentas desenvolvidas no âmbito das Humanidades Digitais conferem à investigação acadêmica.

O Quadro 2 indica que a forma vossa mercê era constantemente grafada com pelo menos uma das palavras por extenso, geralmente vossa, durante todo o século XVI. Há muitos documentos quinhentistas, inclusive, onde a forma abreviada simplesmente não 
aparece. Ao longo do século XVII, no geral, aumentam as ocorrências das duas palavras abreviadas, $V M$, apesar de alguns documentos ainda trazerem ambas as palavras por extenso. No século XVIII, a forma só aparece por extenso em um documento, surgindo abreviada em todos os demais ${ }^{7}$. Nas cartas do século XIX, verifica-se novamente a ocorrência da forma desenvolvida, embora seu uso indique um ato de impolidez (CULPEPER, 2011) ou, nos termos de Brown \& Levinson (1987), um ato invasivo à face do destinatário, como veremos a seguir.

No Quadro 3 trazemos um resumo e a transcrição de trechos das duas missivas oitocentistas em que as formas aparecem desenvolvidas (CLUL, 2014).

Quadro 3 - Trechos de cartas novecentistas

\begin{tabular}{|l|l|l|}
\cline { 2 - 3 } \multicolumn{1}{c|}{} & CARDS7140 & CARDS7149 \\
\hline Resumo & $\begin{array}{l}\text { O autor exige uma resposta a um } \\
\text { contacto anterior e com várias } \\
\text { ameaças. }\end{array}$ & $\begin{array}{l}\text { O autor profere insultos e ameaças } \\
\text { dirigidos ao destinatário. }\end{array}$ \\
\hline Transcrição & $\begin{array}{l}\text { Queira Vossa merçe Responder } \\
\text { logo logo para ivitar conçequen- } \\
\text { çias tristisimas de que se não Liva } \\
\text { o que lhe juro. Reposta sem falta } \\
\text { pelo Correio na forma que lhe de- } \\
\text { tremino. alias não Se } \\
\text { queixe..... }\end{array}$ & $\begin{array}{l}\text { Meu Caro amigo pode Voça merçe } \\
\text { por a quinze dias, Com particular } \\
\text { Recomendaçao, limpe o Cu com } \\
\text { ela - pode mandar Levantar dinhei- } \\
\text { ro Se o tem no Siguro [... }\end{array}$ \\
\hline Autor & Manuel Maria de Saldanha Guedes & Manuel Maria de Saldanha Guedes \\
\hline Destinatário & Gertrudes Rita & Domingos Gonçalves Fominica \\
\hline
\end{tabular}

Fonte: CLUL, 2014.

Os excertos acima comprovam que a forma desenvolvida vossa mercê apresentava no início do séc. XIX um valor bastante descortês, radicalmente distinto de seu valor pragmático inicial. Para um cotejo breve, tomemos a missiva de $n^{\circ} 35$, escrita entre os anos de 1587 e de 1588, que traz um importante exemplo do valor de vossas mercês à época (ver Figura 9 a seguir). Escrita por Joana de Mendanha, mulher culta que dominava latim, condenada e torturada pelo Tribunal do Santo Ofício, a missiva revela uma preciosa rasura: "estado de vosas m suas ilustres pesoas". A observação paleográfica minuciosa, facilitada pelo modo de concepção do corpus do Projeto Post Scriptum, permite a visualização do tachado, que indica uma informação pragmática crucial: àquela altura a forma

\footnotetext{
${ }^{7}$ Informa-se que, em relação ao século XVIII, como eram muitas ocorrências da forma vossa mercê abreviada $V M$, optou-se por selecionar apenas alguns documentos representativos para constar do Quadro 2. Ressalta-se, no entanto, o fato de ter sido encontrada somente uma carta com a forma por extenso no período.
} 
vossa mercê muito provavelmente ainda carregava um alto grau de cortesia e deferência, podendo ser substituída pela expressão "suas ilustres pesoas".

Figura 9 - Trecho da carta quinhentista de no 35 (PSCR1 191)

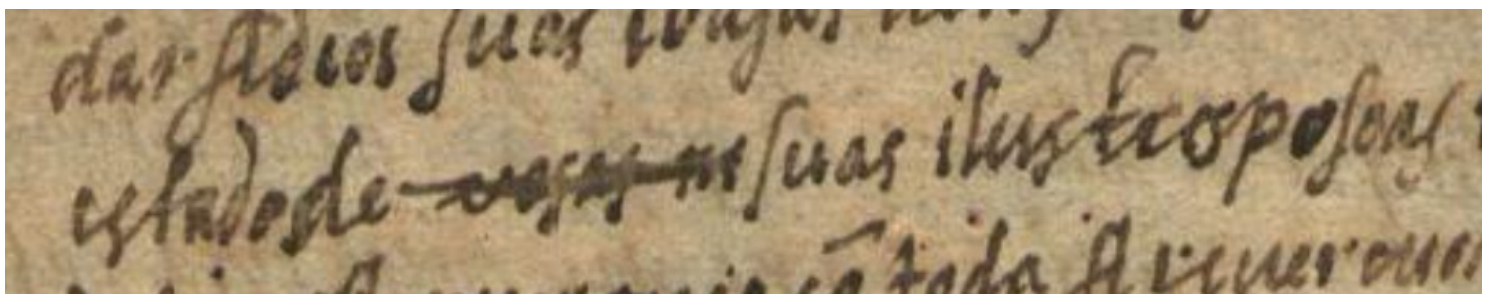

Fonte: CLUL, 2014.

O aumento no uso de abreviaturas para as formas honoríficas de tratamento ao longo do século XVII é fato também verificado em outras línguas europeias, como o alemão. Simon (2003, p. 88) afirma: "Although the employment of abstractions like these in addressee-reference is much older, it first becomes widespread in the 17 th century.”.

A observação paleográfica acurada de documentos modernos indica que as palavras e expressões mais frequentes na língua e também os sufixos mais utilizados estão sujeitos a maior taxa de abreviação. Portanto, o raciocínio oposto tem grandes chances de ser válido: quanto menos frequente um elemento, menor a chance de aparecer abreviado. Se esse for o caso, pode-se afirmar que a forma vossa mercê vai se tornando mais frequente ao longo do século XVI nos documentos de gente comum, cristalizando uma certa tradição diplomática epistolar, até que deixa de ser representada por extenso, tornando-se uma fórmula epistolar, em que aparece rotineiramente abreviada por $V M$ e $V M^{e} / V m^{c e}$, que são quase unanimidade no século XVIII.

\section{As fontes metalinguísticas e uma obra literária quinhentista}

As cartas manuscritas originais e autógrafas analisadas na seção anterior documentam um certo estado de língua, em sua dimensão escrita. É claro que o exame minucioso realizado, do ponto de vista de sua materialidade, permite que se lancem hipóteses mais ou menos seguras sobre a história paralela da língua falada, e mais do que isso, da língua falada pelo povo, que não dominava a arte de escrever. Saber se as pessoas nascidas no século XVI no Reino de Portugal usavam a forma vossa mercê na oralidade é pergunta difícil de ser respondida, mas as fontes metalinguísticas (GONÇALVES \& BANZA, 2013) podem nos fornecer pistas importantes sobre uma parte da língua que necessariamente é fruto de uma reconstrução histórica realizada no presente. 
No Vocabulario Portuguez \& Latino..., do Padre Raphael Bluteau (1712-1728), conforme se observa nas Figuras 10 e 11 a seguir, o termo vossancê era descrito como termo rústico, definido pelo próprio dicionário como homem ou mulher do campo ou da vila, numa clara oposição aos habitantes da cidade.

Figura 10 - Verbetes Vossancê e Vossê

Vossancê. Termo ruftico. Vid.Vof-
fé. Na Farça do Fidalgo a prendiz, traz
Dom Francifco Manoel efta palavra,
para moftrar a rufticidade de hum Mef.
tre de efgrima, que entrando começa af:
fim, fallando com Dom Gil:
. Guarde Deos a Voffancé.
D.Gil. O' Ayo,pois ifto be
O que vos diffe ind a agor a?

A. Poisfe elle termonaótem, Que importa, que falle afjim:

D. Gil. Vem me elle enfinar a mim? Poisenfinayo tambem.

Vossê. Trato ufado com gente infe: rior, entre vòs, \& voffa mercè.

Vosso. Pronome poffeffivo da fegü: da pefío a que fignifica o que he daquel. le, ou daquelles a quem fe falla.Tuss, tua, twom, ( fallando a hum fó) Ve/ter, veftra, vestrum, (fallando a muitos.) Voffos. Plural de voffo. Tui, tue, tua. (fallando a hum ló. ) $v e f t i, v e f t r a, v e f t r a$, fallando a muiros.

Fonte: Bluteau (17) $12-1728$, p. 580).
Figura 11 - Verbete Rûstico

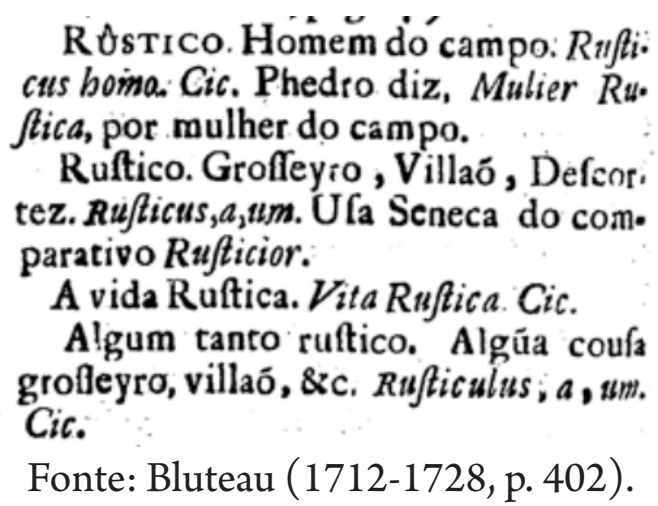

A palavra você (grafada vossé) aparece como sinônimo de vossancê. A abonação vem de texto de autoria de Dom Francisco Manoel de Melo, autor de Feira dos Anexins, que atestaria a primeira ocorrência da forma você. A obra de sua autoria utilizada por Bluteau é O Fidalgo Aprendiz, que foi publicada pela primeira vez em 1665, em Lyon, no interior das Obras métricas ${ }^{8}$. Na farsa, o termo vossancê surge na boca de um rústico mestre de esgrima que a utiliza para tratar um nobre. Cabe destaque o fato de a forma surgir numa típica estrutura formulaica “Guarde Deus a [pessoa do interlocutor]”. Tal estrutura é muito provavelmente uma tradição discursiva bastante forte, permeando tanto a cultura letrada e escrita quanto o campo da oralidade, como se vê na referida passagem.

De qualquer maneira, é digno de nota o lugar híbrido ocupado pela forma, que não era percebida como cortês pelo nobre que a recebeu, entretanto pertencia à semântica da cortesia para o servo que a utilizou. Vê-se então uma certa diglossia nos falares plebeus e nobres, da qual a forma de tratamento é um índice.

\footnotetext{
${ }^{8}$ Para mais informações sobre a transmissão do texto O Fidalgo Aprendiz, consultar Verdelho (1998).
} 
Conforme Bluteau (1712-1728), a forma você, grafada vossê, é definida como um tratamento intermediário entre vós, a essa altura já destituído de sua cortesia, e vossa mer$c \hat{e}$, que ocuparia um lugar mais cortês. Não há abonação da forma, o que parece indicar que a versão manuscrita da obra Feira dos Anexins não teria tido grande circulação quando da época de sua composição, em meados do séc. XVII.

Em obra menos conhecida de Bluteau, o Diccionario Castellano (1721), o autor coloca Vossè como tradução de Usted, comprovando que as formas já circulavam amplamente no século XVII, a ponto de serem dicionarizadas no início do século XVIII.

Madureira Feijó (1734) em sua Ortographia... apresenta conforme a Figura 12, a seguir, os vocábulos vós e vossê.

Figura 12 - Verbetes Vós e Vossê

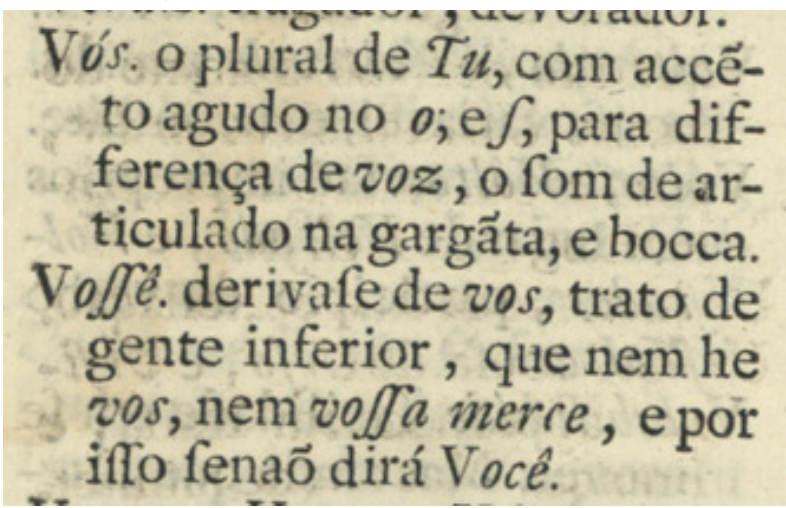

Fonte: Feijó (1734, p. 542).

Feijó (1734) define vós simplesmente como o plural de tu, dando pistas de que a forma usada para um interlocutor único já estava em desuso. Acrescenta-se um comentário de ordem fonética e ortográfica, descrevendo a diferença dialetal entre a pronúncia das fricativas sibilantes apicais e predorsodentais e indicando que a ortografia deveria conservar a variedade da pronúncia. Já no caso de Vossê, Feijó (1734, p. 542) opta por uma descrição mais extensa, abordando três dimensões linguísticas: (i) a morfológica, ao indicar que a palavra teria se derivado de vós; (ii) a pragmática, situando a forma num continuum idêntico ao de Bluteau, entre vós e vossa merce; (iii) fonética ou ortoépica, ao afirmar que não se dirá Você.

Esta última leitura é conclusão obtida a partir da ambiguidade gerada pela afirmação "e por isso senaõ dirá Você". Nesse caso, uma leitura possível, mas menos provável, seria "não se usará você", interpretando-se o verbo "dizer" como sinônimo geral de "falar". Porém, como o próprio título da obra de Feijó indica, Orthographia, ou arte de escrever, e 
pronunciar com acerto a lingua portugueza [...], o autor estava preocupado com a dicção, daí a interpretação de como não deveria ser pronunciado o vocábulo: em vez de Voçê (/s s/ apical), deveria-se dizer Vossê (/s/ predorsodental).

A par das fontes lexicográficas, é importante observar também, sobretudo em pesquisas de pragmática histórica, os textos literários. Comenta-se, a seguir os usos de vossa mercê em uma obra de Jorge Ferreira de Vasconcelos, a Comédia Ulissipo, que foi "publicada provavelmente no ano de 1561 ou em data anterior" (SANTOS, 2006, p. 10). Conforme afirmado na seção inicial, são raras as obras literárias dos séculos XVI e XVII em que constem as formas vossa mercê e você. Cabe ressaltar o que diz a autora do estudo e da edição crítica da obra:

A intriga retrata o meio social da Lisboa quinhentista, tornando-se, deste modo, um testemunho de grande valor documental. [...] Esta comédia apresenta marcas estilísticas específicas e inovadoras. Jorge Ferreira de Vasconcelos é um defensor acérrimo do português, que contrapõe ao castelhano, língua preferencial da corte, ou ao latim, língua de cultura. Ao afastar o português do castelhano e do latim, conferindo-lhe, muito embora, o estatuto de língua românica, o Autor atribui-lhe identidade própria como marca patriótica e, na esteira de Fernão de Oliveira, João de Barros, António Ferreira, partilha a defesa da língua pátria como reduto da identidade cultural. Nesta peça, a língua castelhana e as expressões latinas são utilizadas com características sociais (a Sevillana, os advogados, os cristãos). Mantendo a mesma linha de pensamento, o Autor faz corresponder a cada estrato social o nível de língua apropriado, que, consoante as personagens, ora se aproxima da linguagem da rua, plena de provérbios, ora está próxima da linguagem culta da corte; esta linguagem é enriquecida com citações e máximas de autores da antiguidade clássica, ou com referências a poetas ou composições poéticas dos cancioneiros ibéricos. Mas a característica mais marcante da produção literária deste Autor é a valorização da língua portuguesa, que realiza com objectivos políticos, fazendo o contraponto com a língua castelhana e com o latim. Os jogos de palavras, os antónimos, os provérbios, as máximas, os exemplos, a organização das falas segundo os modelos da retórica antiga enriquecem e revelam um estilo marcado pela diversidade. (SANTOS, 2006, p. 28-32)

Nota-se pela análise acima um autor comprometido com a defesa da língua portuguesa sobre a língua vizinha, a castelhana, e sobre o latim. Nessa tentativa de valorizar a língua, cria níveis linguísticos diferenciados para cada um dos estratos sociais a que pertencem seus personagens.

Vejamos alguns exemplos de uso da forma vossa mercê na comédia, que aparece timidamente, assim como a forma $t u$, quando comparadas à forma vós, preferencial em 
todas as relações ${ }^{9}$ A primeira ocorrência de vossa mercê situa-se na segunda cena, na boca de uma personagem jovem, Glicéria, que conversa com sua irmã, Tenolvia, e com a mãe, Filotecnia. É à matrona que dirige a fala: "Vossa mercê nunca há-de ser por nós, por mais que homem queime as pestanas pela satisfazer nunca é contente.” Trata-se de relação assimétrica ascendente, o que poderia indicar certa cortesia. Porém, acontece num momento específico do diálogo, em que a filha ataca a mãe e a acusa de não defendê-las (ela e a irmã) de seu pai. Nesse momento, prescinde-se da forma vós até então usada e opta-se por vossa mercê. Na sequência, a forma aparece acompanhada de "senhora" no diálogo do criado Hipólito com a donzela Glicéria: "Vossa mercê, senhora, vê como eu ando safado?”. Um terceiro uso vem de Régio, que estava mais acima do estatuto social da criadagem, e utiliza a forma, também acompanhada por "senhor", para se dirigir ao galante Alcino: "Ah senhor, vossa mercê dece logo, e tomará púcaro de agoa asserenada, qual nunca bebeu juiz de porto de Muge?". Novamente antecedida por "senhor”, a forma surge na fala de Costança, mulher viúva para tratar o jovem Alcino: “- Senhor - tornou ela - vossa mercê me quer meter em um negócio muito estranho, e alheo da minha arte.”. Por duas vezes, a forma aparece na estrutura formulaica "Beijo as mãos a vossa mercê". O criado Barbosa utiliza-a também acompanhada de "senhor" para se dirigir a outro criado, Hipólito: "Vossa mercê senhor sabe o que eu tenho sabido de vossa amiga a gentil Florença la bella?”.

O fato de aparecer acompanhada da forma senhor/senhora em muitos diálogos, tanto entre criados quanto entre donzelas e cavalheiros, parece indicar que era forma corrente e que estava associada a uma certa cortesia, ainda que pudesse ser usada de forma irônica, como ato ameaçador da face, como o faz Glicéria em relação à mãe. Além disso, a forma era frequentemente usada na estrutura formulaica "beijo as mãos a[de] vossa mercê”, favorecendo a hipótese de esta configurar uma forte tradição discursiva, tanto na fala quanto na escrita.

\section{Observações Finais}

Pelo exame das fontes metalinguísticas, documentais e da obra literária, discutimos sobre alguns pontos fundamentais na diacronia das formas vossa mercê e você. $\mathrm{O}$ primeiro deles, de natureza metodológica, é a produtividade da associação de áreas do conhecimento próximas, mas que não necessariamente se interconectam: a Filologia, a Paleografia e a Linguística Histórica. É somente a partir do entendimento da Filologia enquanto perspectiva de estudo do texto escrito, associado às observações críticas advindas da Paleografia, que se pode dar conta do estudo de alguns fenômenos linguísticos no

\footnotetext{
9 As formas mais honoríficas vossa excelência, vossa senhoria e vossa majestade não ocorrem no texto.
} 
âmbito da Linguística Histórica. Acresça-se à interdisciplinaridade descrita, os ganhos advindos das Humanidades Digitais, que permitem a criação de objetos novos, a partir, por exemplo, da associação das reproduções fac-similares às camadas de edição do texto.

O segundo ponto que se pretendeu esclarecer é a situação de antiguidade da forma você (considerando a amplitude verificada de formas gráficas) tanto na escrita, conforme comprovação documental, quanto na língua corrente do século XVI. Um achado importante é a retrodatação da palavra você, fundamentada em documentação fidedigna e etimologicamente confiável, cuja primeira atestação passa a ser o ano de 1638. O principal argumento a favor da antiguidade da forma você na língua portuguesa assenta-se sobre o universal conservadorismo da escrita perante a fala. Ou seja, se a forma já aparecia em cartas de cidadãos comuns da primeira metade do século XVII é muito provável que já estivesse na boca dos falantes, assim como estava seu par castelhano usted, ao longo dos quinhentos.

O terceiro ponto, advindo do anterior, é o fato de que ao Brasil, junto à língua de seus primeiros colonizadores, muito provavelmente chega já a forma você, que vai se fixar numa região caracterizada justamente por poucos movimentos populacionais em comparação a outras durante os primeiros séculos da América Portuguesa. Nesse sentido, para algumas regiões do Brasil não se pode falar de você como estratégia inovadora, fruto de uma implementação tardia, ocorrida no séc. XIX ou mesmo no séc. XX. O que parece ter ocorrido no território compreendido pelas Capitanias de São Vicente e de Santo Amaro e, posteriormente, naquele das capitanias que viriam a se constituir a partir daquelas a saber, a de São Paulo, de Minas Gerais, de Goiás e de Mato Grosso - é a fixação da forma você como tratamento generalizado. Somente mais tarde, ao longo do século XIX, período caracterizado por movimentos populacionais intensos, é que a forma você começa a se implementar na região do Rio de Janeiro, zona caracterizada pela forma $t u$.

Nesse sentido, outro ponto que nos parece fundamental na história do português brasileiro, é nos aproveitarmos das pesquisas regionais associando-as necessariamente ao conhecimento sócio-histórico que possuímos sobre a constituição desses territórios e das populações que ali habitaram ao longo dos séculos XVI, XVII e XVIII, principalmente. Dessa forma, poderemos começar a tentar constituir as isoglossas fundadoras do português brasileiro, tão necessárias nos estudos de Linguística Histórica e, assim, os conceitos de inovação e conservação poderão ser relativizados em função da própria história do português brasileiro e não em função do português europeu.

Um último ponto que nos parece importante destacar é que há duas evoluções lin- 
guísticas em paralelo ocorrendo simultaneamente. A primeira é a evolução da forma vossa mercê, que parece acontecer predominantemente na escrita, mas que surge também nas reduções vossancê e similares, próprias da oralidade. Essa evolução tem suas particularidades e é necessário que as investiguemos. Para isso, precisa ser considerada como forma autônoma e não somente como forma genética que origina o atual pronome você. A segunda evolução, esta que é amplamente estudada por ser justamente fundamental na história do PB, é a da forma você, muito mais difícil de ser investigada nos primórdios da América Portuguesa por ser pouco registrada nas fontes documentais. Assim, o estudo inicial dessa forma deve necessariamente se basear em hipóteses elaboradas a partir de edições digitais de manuscritos e de um movimento concentrado de descoberta de novas fontes quinhentistas e seiscentistas.

\section{Referências}

BLUTEAU, Raphael. Vocabulario portuguez \& latino: aulico, anatomico, architectonicco... Coimbra: Collegio das Artes da Companhia de Jesus, 1712-1728. 8 v. Disponível em: http://www.brasiliana.usp.br/dicionario/edicao/1. Acesso em 12 abr. 2019.

BLUTEAU, Raphael. Diccionario Castellano y Portuguez para facilitar a los castellanos el uso del Vocabulario Portuguez, y Latino, Vocabulário Portuguez e Latino, VIII, Lisboa Occidental, Na Officina de Pascoal da Silva, 1721, [6], 3-189.

BROWN, Penelope; LEVINSON, Stephen. Politeness. Cambridge: Cambridge, 1987.

CINTRA, Luís Felipe Lindley. Sobre "formas de tratamento" na língua portuguesa. Lisboa: Livros Horizonte, 1972.

CLUL (Ed.). P.S. Post Scriptum. Arquivo Digital de Escrita Quotidiana em Portugal e Espanha na Época Moderna. Lisboa, 2014. Disponível em: http://ps.clul.ul.pt. Acesso em 12 abr. 2019.

COOK, Manuela. Uma Teoria de Interpretação das Formas de Tratamento na Língua Portuguesa. Hispania, Birmingham, v. 80, n. 3, p. 451-464, sep. 1997. Disponível em: https://www.jstor.org/stable/345821. Acesso em 12 abr. 2019.

COOK, Manuela. Portuguese Pronouns and Other Forms of Address, from the Past into the Future-Structural, Semantic and Pragmatic Reflections. Ellipsis - Journal of the American Portuguese Studies Association, New Brunswick, v. 11, p. 267-290, 2013. Disponível em: https://jls.apsa.us/index.php/jls /article/view/84/105. Acesso em 12 abr. 2019.

CULPEPER, Jonathan. Impoliteness: Using Language to Cause Offence. New York: Cambrige University Press, 2011.

DURÃES, Andreia Maria. Casas de cidade: processo de privatização e consumos de luxo nas camadas intermédias urbanas (Lisboa na segunda metade do século XVIII e início do 
século XIX). 2017. 489 f. Tese (Doutoramento em História) - Instituto de Ciências Sociais, Universidade do Minho, Braga, 2017.Disponível em: https://www.academia.edu/37469076/ Casas_de_cidade_processo_de_privatiza\%C3\%A7\%C3\%A3o_e_consumos_de_ luxo_entre_as_camadas_m\%C3\%A9dias_urbanas_Lisboa_na_segunda_metade_ do_s\%C3\%A9culo_XVIII_e_in\%C3\%ADcios_do_s\%C3\%A9culo_XIX_. Acesso em 24 set. 2019.

FEIJÓ, João de Morais Madureira. Orthographia, ou arte de escrever, e pronunciar com acerto a lingua portugueza para uso do excellentissimo Duque de Lafoens / pelo seu mestre João de Moraes Madureyra Feyjo... Lisboa Occidental: na Officina de Miguel Rodrigues, Impressor do Senhor Patriarca, 1734. Disponível em: http://purl.pt/13. Acesso em 12 abr. 2019.

FRANCO, Daví. Você: uma análise sociopragmática dos seus primeiros registros na literatura. Anais do XVII Colóquio de Pós-graduação e Pesquisa em Letras Neolatinas, Rio de Janeiro, UFRJ, p. 37-44, 2017. Disponível em: http://www.letras. ufrj.br/pgneolatinas/ site/wp-content/uploads/2018/05/Anais-XVII-PPGLEN-vers\%C3\%A3ofinal. pdf\#page $=37$. Acesso em 12 abr. 2019.

GONÇALVES, Maria Filomena; BANZA, Ana Paula. Fontes metalinguísticas para o português clássico: $\mathrm{O}$ caso das Reflexões sobre a Lingua Portugueza. In: GONÇALVES, Maria Filomena; BANZA, Ana Paula. (Coord.) Património Textual e Humanidades Digitais: Da antiga à nova Filologia [online]. Lisboa: Publicações do Cidehus, 2013, p. 73-111. Disponível em: http:/ /books.openedition.org/cidehus/1088. Acesso em 12 abr. 2019.

HOUAISS, Antonio; VILLAR, Mauro. Dicionário Houaiss. Rio de Janeiro: Editora Objetiva e Instituto Antônio Houaiss, 2012. Edição online. Disponível em: http:// houaiss.uol.com.br/. Acesso em: 28 set. 2019.

LOPES, Célia Regina dos Santos et al. A reorganização do sistema pronominal de $2^{\text {a }}$ pessoa na história do português brasileiro: a posição de sujeito. In: LOPES, Célia Regina dos Santos et al. (Org.). História do Português Brasileiro: Mudança sintática das classes de palavras: perspectiva funcionalista. v. 4. São Paulo: Contexto, 2018. p. 24-142.

LUZ, Marilina dos Santos. Fórmulas de tratamento no português arcaico - subsídios para o seu estudo. Revista Portuguesa de Filologia, Coimbra, v. 7, 8 e 9, p. 256-363, 1958.

MENON, Odete Pereira da Silva. A história de você. In: GUEDES, Marymarcia et al. (Org.). Teoria e análise lingüísticas: novas trilhas. Araraquara: LEFCL/ São Paulo: Cult. Acadêmica, 2006. p. 99-160.

MENON, Odete Pereira da Silva. Sobre a datação de você, ocê e senhorita. Fórum Linguístico, Florianópolis, v. 6, n. 1, p. 45-71, 2009.

MONTE, Vanessa Martins do. Correspondências Paulistas: As formas de tratamento em cartas de circulação pública (1765-1775). São Paulo: Humanitas/FAPESP, 2015.

PAIXÃO DE SOUSA, Maria Clara. Texto digital: uma perspectiva material. Revista da ANPOLL, Florianópolis, v. 1, p. 15-60, 2013. 
SANTOS, Maria do Rosário Calisto Laureano. A Comédia Ulissipo de Jorge Ferreira de Vasconcelos: Estudo e edição crítica. 2006. 536 f. Tese (Doutoramento em Estudos Portugueses) - Faculdade de Ciências Sociais e Humanas, Universidade Nova de Lisboa, Lisboa, 2006. Disponível em: http://hdl.handle.net/10362/15004. Acesso em 12 abr. 2019.

SIMON, Horst. From pragmatics to grammar. Tracing the development of respect in the history of the German pronouns of address. In: TAAVITISAINEN, Irma; JUCKER, Andreas H. (Ed.). Diachronic Perspectives on Address Term Systems. Amsterdam / Philadelphia: Benjamins, 2003. p. 85-123.

TOLEDO NETO, Sílvio de Almeida. Datação e localização dos tipos de escrita: informações relevantes para a Crítica Textual? In: LOSE, Alícia Duhá; SOUZA, Arivaldo Sacramento de. (Org.). Paleografia e suas interfaces. 1ed. v. 1. Salvador: Memória \& Arte, 2018, p. 292-303.

VERDELHO, Evelina. As edições de O Fidalgo Aprendiz, de D. Francisco Manuel De Melo. Humanitas, Coimbra, Universidade de Coimbra, v. 50, tomo II, p. 867-886, 1998. Disponível em: https://www.uc.pt/fluc/eclassicos/publicacoes/ficheiros/humanitas 50/49.2_Verdelho.pdf. Acesso em 12 abr. 2019.

VIARO, Mário Eduardo; BIZZOCCHI, Aldo Luiz. Proposta de novos conceitos e uma nova notação na formulação de proposições e discussões etimológicas. Alfa, São Paulo, v. 60, n. 3, p. 579-601, dez. 2016. Disponível em: http://www.scielo.br/scielo.php? script=sci_arttext\&pid=S1981-57942016000300579\&lng=pt\&nrm=iso. Acesso em 11 abr. 2019.

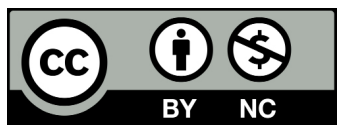

Data de submissão: 13/04/2019

Data de aceite: 07/10/2019 